Final version:

Lindgreen, A. and Vanhamme, J. (2003), "To surprise or not to surprise your customers: the use of surprise as a marketing tool", Journal of Customer Behaviour, Vol. 2, No. 2, pp. 219-242. (ISSN 1475-3928)

For full article, please contact LindgreenA@ cardiff.ac.uk

\title{
To Surprise Or Not To Surprise Your Customers: \\ The Use Of Surprise As A Marketing Tool
}

\section{Dr. Adam Lindgreen, Eindhoven University of Technology ${ }^{1,2}$}

\section{Dr. Joëlle Vanhamme, Erasmus University Rotterdam ${ }^{3}$}

Keywords: customer retention, emotions, relationship marketing, satisfaction, surprise

\footnotetext{
1 Adam Lindgreen, Department of Accounting, Finance, and Marketing, Faculty of Technology Management, Paviljoen J. 11, Eindhoven University of Technology, Den Dolech 2, P.O. Box 513, 5600 MB Eindhoven, the Netherlands. Telephone: + 31 - (0) 40247 3700. Fax: + 31 - (0) 40246 5949. E-mail: a.lindgreen@tm.tue.nl.

${ }^{2}$ The authors contributed equally and have been listed alphabetically. They would like to give thanks to Professor, dr. Brett Collins for much appreciated advice, as well as their colleagues at different conferences with whom they discussed the idea of using surprise as a tool for retaining customers. They also appreciate very much the advice of the editor of The Journal of Customer Behaviour, Professor, dr. Michael Baker, and the two anonymous reviewers.

${ }^{3}$ Joëlle Vanhamme, Department of Marketing, Erasmus University Rotterdam, P.O. Box 1738, 3000 DR Rotterdam, the Netherlands. Telephone: + 31 - (0) 10408 1194. Fax: + 31 - (0) 1040 89011. E-mail: jvanhamme@fbk.eur.nl.
} 


\title{
To Surprise Or Not Surprise Your Customers:
}

\section{The Use Of Surprise As A Marketing Tool}

\begin{abstract}
It has been contended that companies must move from satisfying their customers to delighting them (Rust, Zahorik and Keiningham, 1996). It has also been observed that features that can be used to delight are those that are "surprisingly pleasant" (Rust and Oliver, 2000: p. 87). Many relationship marketing activities are being copied and therefore fail to provide for a long-term strategic advantage to the companies that originally launched them. Moreover, some of such activities do not work as originally intended. This article examines when and how surprise can be applied as a marketing tool in retaining a company's customers. A review of the existing literature on (1) the use of relationship-based marketing and emotion-based marketing and (2) the emotion of surprise suggests that it is close to impossible for a company to copy emotion-based marketing activities. Interestingly, the emotion of surprise has recently been proposed as being appropriate for emotion-based relationship marketing. This article argues that surprise can be an extremely efficient marketing tool, but that marketers need to be aware that some situations are more suited for using surprise than other situations. In order to reach this conclusion the article reviews empirical research on the emotion of surprise and its influence on marketing variables such as customer satisfaction and retention and trust.
\end{abstract}




\section{Background}

Companies are seeking to satisfy their customers, but Rust and his colleagues contend that companies really "need to move beyond mere satisfaction to customer delight" (Rust, Zahorik and Keiningham (1996: p. 229). They also note that features that have "the capacity to delight are those that are [...] surprisingly pleasant" (Rust and Oliver, 2000: p. 87). This is an important observation. Consider, for example, the popular loyalty schemes many of which are built around surprising the customers: as we shall see shortly these schemes were meant to increase customer satisfaction but, in fact, do not work as the companies had planned for. Based upon a review of the existing literature on (1) the use of relationship-based marketing and emotion-based marketing and (2) the emotion of surprise, our article examines when and how surprise can be used as a marketing tool in retaining a company's customers. Overall we argue that surprise can be an extremely efficient marketing tool, but that marketers need to be aware that some situations are more suitable for surprise activities than other situations.

\section{Goals and Organisation of Paper}

The article is structured around three parts. In the first part we discuss how companies increasingly are emphasising customer retention as opposed to customer attraction (e.g. Dowling and Uncles, 1997; Reichheld, 1996). We also look at how relationship-based marketing activities often are being copied and thus fail to provide for a long-term strategic advantage to the companies that originally launched them (e.g. Sheth and 
Randall, 2001), as well as how such activities do not even work as originally intended by the companies (e.g. Fournier, Dobscha and Mick, 1998).

We then examine emotional variables and their influence in marketing in the second part. The marketing literature suggests that it is almost impossible for a company to copy emotion-based marketing activities that therefore can result in a powerful competitive advantage (Barnes, 2001; Colgate, Stewart and Kinsella, 1996; Heil, Parker and Stephens, 1999; Robinette, Brand and Lenz, 2001; Rust, Zeithaml and Lemon, 2000). We consider, and describe in detail, the emotion of surprise that has recently been proposed as being appropriate for emotion-based relationship marketing (Vanhamme and Lindgreen, 2001a, 2001b; Vanhamme, Lindgreen and Brodie, 1999; see also Schmitt, 1999; Woolf, referenced in Mitchell, 1995).

The final part is based upon a review of empirical work on the emotion of surprise and its influence on marketing variables such as customer satisfaction, retention and trust (e.g. Vanhamme and Lindgreen, 2001a, 2001b). In the conclusions we first summarise our main findings before we deal with avenues for future research.

\section{Relationship-based Marketing}

Relationship marketing has attracted considerable interest over the past decade (e.g. Best, 2004; Cigliano, Georgiadis, Pleasance and Whalley, 2000; Dowling and Uncles, 1997; Reichheld, 1996). The enormous changes in the market environment explain to a large 
extent why companies are now mainly focusing on customer retention as opposed to customer attraction. The changes include environmental change, globalisation of markets, changes in industrial structure, information revolution and rising customer expectations (Brookes, Brodie and Lindgreen, 2000; Doyle, 2000; Sheth and Sisodia, 1999). Alone and together, these changes have resulted in a situation where marketers are now placing a much greater emphasis on managing and retaining their marketing relationships (Day, 2000; Grönroos, 2000; Gummesson, 1999; Hunt, 2000; Peck et al., 1999; Webster, 2000). It is interesting to appreciate, however, that many companies are approaching marketing pluralistically, with transaction marketing (i.e. marketing through the 4Ps; Borden, 1965) being carried out in conjunction with relationship marketing (Brodie, Coviello, Brookes and Little, 1997; Coviello, Milley and Marcolin, 2001; Lindgreen et al., 2000).

The use of the popular loyalty schemes is one case in point of how companies have sought to implement relationship marketing. Although such schemes have been around for a long time - for example, Barnes (2001) describes S\&H Green Stamps whose trading stamps were introduced more than 100 years ago - loyalty schemes are now abundant and include the frequent flier schemes of most airlines and their alliances (e.g. Delta, KLM, One World and Star) and many similar schemes from companies such as American Express, General Motors, Barnes \& Noble, Blockbuster Video, Holiday Inn, Hallmark Cards, Toyota/Lexus, John Deere, Tesco Stores and Shell. It is thus apparent that relationship marketing is being pursued across many very different business sectors. Palmer (1998) nevertheless observes that there has been few published long-term studies of the effectiveness of relationship marketing, and many loyalty schemes are easily 
copied, which means that such schemes fail to provide for a long-term strategic advantage to the companies that originally launched them. For example, Tesco Stores launched its Clubcard in 1993 and although it enjoyed an initial significant competitive advantage other UK food retailers soon introduced their loyalty schemes: Safeway's ABC scheme in 1995 and Sainsbury's Reward scheme in 1996 (Brassington and Pettitt, 2000; Palmer, 1998; Sheth and Randall, 2001). Another example is the worldwide airline industry where Gilbert and Karabeyekian (1995) note that loyalty incentives have rapidly become a sector norm that customers simply expect.

Fournier, Dobscha and Mick (1998: p. 44) write, "Relationship marketing is powerful in theory but troubled in practice. To prevent its premature death, we need to take the time to figure out how and why we are undermining our own best efforts, as well as how we can get things back on track". Relationship marketing is here defined as attracting, developing and retaining customer relationships (see, for example, Dwyer, Schurr and Oh, 1987; Gummesson, 1999; Jackson, 1985; Morgan and Hunt, 1994). Fournier and her colleagues describe how customers are being invited to participate in numerous loyalty schemes, yet customer satisfaction ratings remain at an all-time low. Although companies are trying to learn more about their customers so that they can provide "features and services to please every possible palate" (Fournier, Dobscha and Mick, 1998: p. 43) they do not always succeed in doing so. Some mail order catalogue companies, for example, send out reminders to customers that now is the time to surprise loved relatives with presents not knowing that these relatives have been deceased for a long time! (For a similar idea, see Boulaire, 2003.) Other customers are being served the usual type of 
drinks or snacks whenever they check into their favourite hotel although they would now like the room service to change, or they are having their lives made easier by consistently reliable service, which, however, is boring (Brown, 2001). In short, companies are failing to understand that some customers may take pleasure in being both teased and tantalised (Brown, 2001). As a result, these customers experience a loss of control, vulnerability, stress and victimisation - and stay away from the company (Bell and Zemke, 1987; Fournier, Dobscha and Mick, 1998; Heskett et al., 1994).

\section{Emotion-based Marketing}

It has been suggested that emotions are key for companies that wish to develop personalised relationships with their customers and, in doing so, retaining these customers. For example, Heil, Parker and Stephens (1999: pp. 60-61) contend that genuinely personal relationships between a company and its customers are based "more on feeling than on 'stuff'; on emotion, as well as reason; and on intangibles as well as metrics. Because, after all, what is loyalty if not something that, first and foremost, you feel and experience on an emotional level?"

In a similar vein, Colgate, Stewart and Kinsella (1996: p. 24) observe that "[Loyalty] is more than a set of behaviors. It is recognized that loyalty has a behavioral dimension but that it also has an attitudinal aspect". Barnes (2001) argues that one of the drivers of customer satisfaction consists of emotional elements, and that companies should seek to enhance 'respect', 'appreciation', 'recognition' and 'feeling of value' while try to reduce 
'confusion', 'frustration', 'disappointment' and 'neglect' at the same time. The work of Yu and Dean (2001) explores the role of emotions in satisfaction and finds that both positive and negative emotions, as well as the cognitive component of satisfaction correlate with customer loyalty. They also find evidence to suggest that the affective component actually is a better predictor of customer loyalty than the cognitive component.

Robinette, Brand and Lenz provide an account of the emotion-based marketing strategy behind Hallmark's success at capturing customers, and define 'emotion marketing' as "the enterprise-wide pursuit of a sustainable connection that makes customers feel so valued and cared for they'll go out of their way to be loyal" (Robinette, Brand and Lenz, 2001: p. 4). The authors argue that it is almost impossible to replicate emotional marketing strategies, which can therefore constitute a powerful competitive advantage. Davis and Meyer (1998) describe the exchanges between buyers and sellers as a web of economic, information and emotional exchanges.

In a discussion of customer retention schemes, Rust, Zeithaml and Lemon (2000) contend that companies should strengthen the relationships with their customers through emotional ties. However, such affinity and emotional connection programmes depend on the company's ability to identify their customers' interest and form an emotional link with them, the authors observe. 


\section{Surprise In Marketing}

There is strong support for using surprise in emotion-based marketing. For example, it has been argued that loyalty schemes should follow the rules illustrated in Table I (Woolf, referenced in Mitchell, 1995). Some of these rules apparently are based upon surprise strategies such as occasionally offering double points, having weekly prize draws and, to a lesser extent, inviting customers to special events or participating in new variations of the scheme.

Insert Table I About Here

Schmitt (1999) presents an approach with which companies can create holistic experiences for their customers. The approach works through five different experiences, namely 'sense', 'feel', 'think', 'act' and 'relate'. The objective of the 'think' experience is to encourage customers to engage in elaborative and creative thinking, which may result in the customer re-evaluating the company and its products. A 'think' experience works best when a surprise is created visually, verbally or conceptually, when an intrigue is added, and when the situation provokes a surprise reaction in the customer. Schmitt argues that the surprise must be positive so that the customers are delighted.

There are cases where companies have been using surprise, especially in advertising and promotion. The Wall Street Journal uses "unexpectedly dynamic fashionlike photographic images to engage potential readers' and advertisers' thinking" (as quoted in 
Schmitt, 1999: p. 149), and makes surprising points in its ads. Other cases include the surprising slogan of the New York Police Department: 'CPR: Courtesy, Professionalism, and Respect' and Levi's campaign that implied that competing designers had started wearing 501's: "Calvin wore them", "Ralph wore them", etc.). Ambient advertising and the so-called ' teaser ads' are other examples of advertising based upon a surprising effect: Ambient ads are placed in settings that are unusual (e.g. a golf hole) and, therefore, trigger surprise (Bainbridge and Crutis, 1998). Teaser ads are often used prior to the introduction of new products as a means of preparing the market. The ads are also surprising in that they do not depict or mention the actual product; only toward the end of an advertising campaign does the customer get to know the product (Belch and Belch, 1995; Stevens, 1992). In-store instant couponing is another example and is frequently used by fast moving consumer goods manufacturers and retailers. (Of note: a recent study by Heilman, Nakamoto and Rao (2002) shows that such 'surprise coupons' result in an increase in the number and dollar value of unplanned purchases made.)

We find further support for using surprise in a marketing strategy from the augmented product concept. In their market offering, Levitt (1969, 1980, and 1981) argues, marketers must think through five levels of the product each of which adds more value to the consumer. These levels are core benefit, basic product, expected product, augmented product and potential product. That is, the five product levels constitute a consumer value hierarchy. The augmented product and the potential product often provide unexpected and positive surprising benefits to the customer such as seeing a basket of fruit in the hotel room for the first time. The five-product level framework can be used for products, 
services and combinations of products and services (see, for example, Lovelock, 1994, 1995). The Kano diagram (referenced by, for example, Johnson 1998) includes the same kind of idea. In their categorisation of product attributes, Kano and his colleagues define 'excitement attributes' as unexpected and thus surprising, but highly appreciated benefits that will increase customer satisfaction incommensurately. Pine and Gilmore (1999) echo this arguing that surprise is a tool that can transform common products and services into outstanding and memorable consumption experiences (e.g. a shoeshine boy telling a funny story while polishing a customer's shoes).

\section{The Emotion Of Surprise}

Despite the fact that 'surprising your customers' appears to be in vogue, our understanding of this emotional variable in a marketing context is rather limited and originates largely from the psychology literature. Although there have been calls for a theoretical framework to be developed for surprise (Oliver, Rust and Varki, 1997; Westbrook and Oliver, 1991) and that this particular emotion be investigated in a marketing context (e.g. Derbaix and Pham 1989) only few researchers have attempted to examine the effect(s) of surprise on different marketing variables such as word-of-mouth, customer satisfaction and customer retention (e.g. Derbaix and Vanhamme, 2003; Vanhamme, 1999; Vanhamme, Lindgreen and Brodie, 1999, Vanhamme and Snelders, 2001). We will next consider, and describe in detail, the emotion of surprise. 
Surprise is a short-lived emotion (e.g. Derbaix and Pham, 1991; Meyer, Niepel, Rudolph and Schützwöhl, 1994; Plutchik, 1980) that results in a specific pattern of reactions (Reisenzein, Meyer and Schützwöhl, 1996). This has been illustrated in Figure 1. Surprise consists of physiological changes (e.g. changes in heart and respiration rates), as well as behavioural changes (e.g. changes in facial expressions or interruption of ongoing activities, which enables the surprised people to better focus their attention on the surprising elements and, by doing so, to retain these elements). Surprise also consists of the surprised people's subjective experience. (For a detailed review, see Vanhamme and Snelders, 2001.)

\section{Insert Figure 1 About Here}

When products, services or attributes are unexpected or misexpected they elicit surprise (Ekman and Friesen, 1975; Izard, 1977; Scherer, 1984). 'Unexpected' denotes vague and not well-defined expectations about a product, service or attribute whilst 'misexpected' denotes precise expectations about a product, service or attribute that nevertheless do not occur. Both unexpected and misexpected products, services or attributes form a schema discrepancy (Meyer, Niepel, Rudolph and Schützwöhl, 1994; Schützwöhl, 1998). A schema is a type of private, normally informal, inarticulate and unreflective theory about the nature of objects, events or situations (Rumelhart, 1984). The appropriateness of a personal schema is continuously (and relatively unconsciously) checked against the surrounding environment (Scherer, 1984). Surprise is elicited as soon as reality diverges from the schema and results in processes that aim at eradicating the schema discrepancy, 
which can lead, if necessary, to an updating of the schema (Meyer, Niepel, Rudolph and Schützwöhl, 1994).

Despite the fact that the emotion of surprise is neutral it is frequently succeeded by another emotion that colours it positively (e.g. surprise + joy) or negatively (e.g. surprise + anger), which explains why people talk about good/positive surprises and bad/negative surprises (Ekman and Friesen, 1975; Meyer, Niepel, Rudolph and Schützwöhl, 1994). In this paper, the terms 'positive surprise' and 'negative surprise' also refer to the blend of surprise with a subsequent positive and negative emotion, respectively. It is also worth mentioning that surprise, through its intrinsic arousal, amplifies subsequent affective reactions (Charlesworth, 1969; Desai, 1939) implying that people who feel joy (anger) after having been surprised will feel more joyful (be angrier) than if they had not previously been surprised.

\section{Surprise, Customer Satisfaction And Customer Retention}

Positive surprise (i.e. surprise combined with a subsequent positive emotion) is, as mentioned earlier, believed to lead to customer delight (Rust and Oliver, 2000). Delight is considered to be the highest level of customer satisfaction and is thought to translate into customer retention levels that are higher than those that can be achieved through lower levels of satisfaction (Rust, Zahorik and Keiningham, 1996). Support for the relationship between customer satisfaction and customer retention is found throughout much of the 
marketing literature (e.g. Bearden and Teel, 1983; Bolton and Drew, 1991; Jones and Sasser, 1995; Reichheld, 1996; Sheth and Sisodia, 1999).

It should be noted that some researchers, however, have questioned the relationship. (For a review of such studies see, for example, Strauss and Neuhaus, 1997.) Storbacka, Strandvik and Grönroos (1994) argue that the customer satisfaction $\Rightarrow$ customer retention link is too oversimplified. (The same is true for customer dissatisfaction $\Rightarrow$ customer defection.) There are thus situations where dissatisfied customers continue to place their orders with the same company, e.g. there is only this one company in the market (such as phone service, water or hospitals) or switching barriers are high, whilst satisfied customers patronise competitors hoping that the first company will reduce its prices (Best, 2004; Dick and Basu, 1994; Lindgreen and Pels, 2002; Mittal and Lassar, 1998; O'Malley, 1998). Another example is the so-called 'service paradox' where the less profitable customers in fact are more satisfied than the more profitable ones the reason being that the latter customers will expect better services or products meaning that the risk of something going wrong is relatively high (Gummesson, 1999).

The idea of a positive relationship between surprise and delight is rooted in Plutchik's work (1980), which suggests that delight results from a combination of two emotions, surprise and joy. Oliver and Westbrook report some indirect evidence for the surprise satisfaction relationship (Oliver and Westbrook, 1993; Westbrook and Oliver, 1991). Using cluster analysis on the emotions that consumers went through during a product/service consumption experience, the studies identified a cluster of consumers 
scoring high on surprise and joy; these consumers were more satisfied than consumers from any other cluster. Likewise, the exploratory surveys by Oliver, Rust and Varki (1997) and Mano and Oliver (1993) suggest the existence of a relationship between positive surprise and satisfaction with a LISREL analysis supporting the causal path of arousal $\Rightarrow$ positive emotions (or, more generally, positive affective reactions as in the Mano and Oliver study) $\Rightarrow$ satisfaction.

A closer examination of the studies' measures for arousal reveals, however, that it was something rather close to surprise that was measured, as two out of the three items of the DES scale for surprise (Izard, 1977) were used. (The three items of the DES scale (an abbreviation for differential emotion scale) for surprise measures the extent to which a person feels surprised, astonished and/or amazed. The scale is a Likert scale from 1 to 5.) In a recent exploratory diary study Vanhamme (2001) confirms the existence of both a direct relationship and an indirect relationship (via positive emotions) between positive surprise and satisfaction. However, this study, which involved the purchasing and/or consumption experiences of a wide range of products and services, was based upon correlation analysis only.

Vanhamme and Snelders (2001) propose two possible theoretical mechanisms underlying the positive impact of surprise on satisfaction: (1) response contagion and (2) category accessibility. Under the former mechanism the positive surprise-satisfaction relationship stems from the intrinsic arousal that is part of the emotion of surprise and that amplifies the succeeding positive affective reactions, which are elicited by the purchasing and/or 
consumption experience and, in turn, enhance the level of satisfaction. It should be appreciated that surprise can also enhance the satisfaction response directly since satisfaction is partly affective (e.g. Oliver, 1997). Under the latter mechanism the surprising event leaves strong traces in a the surprised person's memory (Figure 1), which make any information related to this particular event highly accessible when that person has to form a judgement such as a satisfaction judgement (Cohen and Areni, 1991; Westbrook and Oliver, 1991). Moreover, positive emotions in a surprising purchasing or consumption experience are likely to be more intense as a result of the amplifying property of surprise and, therefore, lead to more salient and accessible memory traces (Izard, 1977; Tomkins, 1980; Westbrook, 1987). Research on social judgement shows that accessible knowledge of a stimulus will disproportionately influence the person's judgement about the stimulus (Bruner, 1957; Higgins, 1996; Wyer and Srull, 1989). This implies that positive elements of the purchasing and/or consumption experience will have a bigger impact on the level of satisfaction when they are surprising since surprise leads to more accessible information. It should be noted that the response contagion mechanism also could be operative in this case because when the memory of an emotional experience is recalled it has the capacity to elicit the same emotions (Cohen and Areni, 1991; Vanhamme and Snelders, 2001).

Despite these theoretical clarifications, little research has investigated the relationship between positive surprise on the one hand and customer delight and customer retention on the other hand; and almost no research has examined the impact of negative surprise on customer delight and customer retention. The empirical work of Plutchik (1980), 
though, provides some directions for future research. He found that surprise + anger results in outrage and that surprise + sadness leads to disappointment (Table II).

\section{Insert Table II About Here}

Schneider and Bowen (1999) recently conceptualised outrage as the mirror image of customer delight and suggested that outrage is the cause of customer defection and 'terrorism' (i.e. customers share their outrage with other customers and exaggerate each time they do so). The causal path of arousal $\Rightarrow$ negative affective reactions $\Rightarrow$ dissatisfaction was also reported in the empirical work of Mano and Oliver (1993). Using a large set of different products and services, Vanhamme (2001) confirmed this indirect path although she also showed that negative emotions do not fully mediate surprise's influence on satisfaction. From a theoretical point of view, the notion that negative surprise enhances customers' dissatisfaction is likely to be based upon the same two mechanisms underlying the relationship between positive surprise and customer satisfaction (Vanhamme and Snelders, 2001).

The qualitative study by Vanhamme and Lindgreen (2001a) also offers insights into the disastrous consequences that negative surprise has on customer satisfaction and retention, as well as on the customers' perception of and trust in the company and in the company's products. The authors looked at the impact of negative surprise elicited by the deceptive gifts that some mail order catalogue companies give to their customers. Such gifts may be 'some super sound hi-fi equipment', which turns out to be old-fashioned headphones for a 
Walkman, and a 'family pancake griddle' that, in fact, can only make bite-sized pancakes. These gifts elicit negative surprise because a letter, which was sent prior to the customers, contained illustrations and/or descriptions that were misleading and that lead the customers to build a schema, which was divergent from the reality and, therefore, triggered a negative customer evaluation of the experience: the real gift was not as nice as the gift in the schema. The negative surprise resulted in disappointment or outrage, as well as the customers mistrusting, and having a bad perception of, the company and its products. Overall, the relationship marketing strategy was being jeopardised because "trust is ultimately the glue that holds a relationship together over the long haul" (Boone and Kurtz, 1999: p. 339).

\section{Managerial Implications And Applications:}

\section{The Use Of Surprise As A Marketing Tool?}

The problem for the mail order catalogue companies was that in their quest for surprising their customers positively they offered them free gifts, which turned out to be a negative experience because of the way that these gifts had been advertised. Vanhamme (2000) reports on similar problems relating to controlling the polarity of surprise. That is, the control of the emotions that are experienced after surprise. The author's aim was to elicit a positive surprise in an experimental setting. Her results, however, showed that negative surprise was elicited rather than positive surprise. In two laboratory experiments in Vanhamme (2002), a similar phenomenon was encountered. 
In the first experiment the aim was to elicit a positive surprise under the first experimental condition and a negative surprise under the second experimental condition, but the results revealed that the manipulation did not succeed for all respondents. The product supposed to be positively surprising was a strawberry yoghurt that came in an individual package, with or without a plastic spoon that could be folded and hidden in the package. Under each of the experimental conditions the participants were asked to eat three yoghurts. Their discovery in the first experimental condition of a spoon in the third yoghurt wrapping was thought to be a positive surprise, as the previous two yoghurts had not contained any spoons; moreover, at no time was it mentioned that there would be a folded spoon in the yoghurt wrapping. Under the second experimental condition a negative surprise was believed to result from the absence of a spoon in the third yoghurt wrapping, as such a spoon had been a part of the first two yoghurts. The data from the experiment are interesting: of the 65 people under the two experimental conditions seven participants were not surprised at all; two participants were positively surprised where the aim had been to create a negative surprise; and three were negatively surprised where the opposite had been planned for.

In the second experiment the product-service, which the participants bought and consumed, was a subscription to a virtual museum visit. It was expected that a positive surprise would result from the sudden appearance on the screen, and the subsequent printout, of a coupon, which could be redeemed for a book free of charge, after the participants had made their first visit and paid for the virtual museum subscription. Again, the participants had not been told about the gift prior to the experiment. The 
negative surprise was believed to happen when the participants, after having made the virtual museum visit and paid the subscription, were told that they would no longer receive a book free of charge because the company had run out of books. In that part of the experiment the participants had been informed that the free book was part of the subscription. The data showed that out of the 62 who participated in the experimental conditions two participants were not surprised; two participants were positively surprised where the aim had been to make a negative surprise; and two participants were negatively surprised where it had been hoped that they would have been positively surprised.

The manipulation of surprise thus went wrong in one out of five participants in the yoghurt experiment, and one out of ten participants in the virtual museum experiment. Further analysis revealed that the failure in manipulating surprise and its polarity could be explained by the specific schemas of the participants. For example, in the positively surprising condition of the first experiment one participant was negatively surprised because he thought the plastic spoon was not made from materials that were ecological. Other participants were not surprised because they had already come across a spoon that could be folded (e.g. when flying Virgin Express within Europe) and often experienced these spoons to be either missing or broken. In other words, the success of any marketing strategy, which is built upon using surprise, very much depends on the extent to which the company knows the schema of its customers.

But it is very difficult to obtain perfect knowledge of the schemas of customers in a mass market, or of customers who engage only in short-time, discrete marketing exchanges 
(i.e. transaction marketing). In such situations a company has only little knowledge of its customers, and the risk of eliciting negative surprise instead of positive surprise, or no surprise at all, is very high. This is in stark contrast to situations where the company has an intimate knowledge of its customers because these engage in long-term, ongoing marketing exchanges (i.e. relationship marketing). Vanhamme and Lindgreen (1999) use the marriage analogy to explain the difference. A marriage is a long-term relationship, and both partners are aware of each other's wants and needs. It is possible for the partners to find positively surprising presents for each other because they know each other so well. We argue that in a situation of transaction marketing it is better to avoid trying to create surprise and, instead, spend all marketing efforts on providing the customers with information as perfect and complete as possible for making a decision about which product or services, if any, to purchase (Box 1 in Figure 2). This is because if the company fails to surprise its customers positively and, in fact, surprises them negatively the effect of this might be very serious in terms of the customers stating that they experience little satisfaction with the company, and that they have little trust in the company and no wish for engaging in long-term relationships with the company.

It has also been noted that surprise ought not to be used unless the performance of the product or service is as the company has promised it will be, i.e. zero default (Pine and Gilmore, 1999). A positive surprise cannot compensate for a product's or service's failure. Again, the effect of using surprise in such a situation could even be worse with customers arguing that the company should have spent the money on improving the product or service instead of sending out free gifts, for example (Vanhamme and Lindgreen, 1999). 
If zero default in performance cannot be achieved the company should stay away from using surprise (Box 2 in Figure 2).

Rust and Oliver (2000) examined the potential problem of a company's use of positive surprise, which could 'raise the bar' of customer expectations and, as a result, not eliciting positive surprise the next time or, even, leading to a negative surprise if the original positively surprising element is no longer part of the company's product or service. That is, the customers update their schema when they are positively surprised the first time so that in subsequent purchasing and/or consumption experiences they expect this new schema to hold true. The bar of customer expectations is thus raised and the cost to the company is increased because if it does not deliver (any longer) the element(s), which had previously been used to create the positive surprise, the customer might be negatively surprised. Moreover, the original benefits of the positive surprise are no longer existent, as the customers have updated their schema! Whether, in fact, such an escalation takes place will be dependent upon the extent to which it is possible for the company to communicate to its customers that they cannot take the surprising feature for granted. For example, two passengers, who are Gold members of a frequent flyer programme, are upgraded from Economy to Business, and update their schema at the same time thus expecting that the same will happen in the future. If, on the other hand, an employee with the flight company explains that the upgrading cannot be expected the next time (i.e. the upgrade took place because of very special circumstances), the risk of the passengers updating their schema to expect upgrading in future is now reduced significantly, and the chances are that they will still be positively surprised next time they fly with the 
company. Another example includes restaurants such as Planet Hollywood. Upon entering the first time, patrons are surprised to see memorabilia from famous performers filling the entire restaurant, but then update their schema so that they are not surprised the next time they come to Planet Hollywood. The situation would be different if the restaurant owner decided to change the theme of the restaurant every so often. If the owner does not announce the restaurant's theme, then after some time patrons will expect the theme to change although they still do not know what the theme will be at any given day and, therefore, they will be surprised.

It could be that there are situations where employing surprise is likely to be more profitable. For example, it would seem to make sense using surprise more frequently for services than for goods because it is probably costlier and less easy for the company to add surprising elements (or to change current surprising elements when their effect start to wear out) to systematised and centralised products/services or to standardized components of product and service offerings than to flexible components of such offerings. It is thus much easier for a bank employee to say 'happy birthday' to one of his customers or to place a bunch of flower inside a newly purchased car than to change a production setup so that it allows accommodating for the surprising element.

Overall, if a company decides to use a marketing strategy of surprise it thus needs to invest time in understanding its customers and their schema in order to create aspects in or around the product or service that are positively surprising. One case in point is consultant companies who first find out about their clients' hobbies before giving them a 
present related to this hobby such as a free ticket for a soccer match. It is interesting that positive surprises do not need to be especially expensive with examples including a greeting card or a box of chocolates on a client's birthday or a lottery ticket to customers one year after they first made a purchase in the shop. By using lotteries it is often possible to avoid that customers update their schema because the customers know that the surprise happened due to chance.

It should be emphasised, though, that there are cases in which is impossible to avoid schema-updating: A new design for a car may be chosen in order to surprise customers (e.g. Renault's European launch of its Twingo) but such a surprise is a 'one shot surprise'. That is, the customers will experience surprise only the first time they see the new car, and no type of communication could possibly prevent customers from updating their schema under those circumstances. In summary, the company should stay away from using surprise (see Box 3 and Box 4 in Figure 2) unless the purpose of surprise is not to create satisfaction and loyalty in the long run but rather to attract new customers (as was the case for Twingo), and, at the same time, other marketing tools have been implemented in order to achieve the long-term goals of satisfaction and loyalty. This must not, however, jeopardise future profits for the company, and it is important to evaluate the impact on the firm's future revenues. 


\section{Conclusions And Future Research}

The marketing literature has contended that companies must move from satisfying their customers to delighting them, and features that can be used to delight are those that are surprisingly pleasant. This article has contributed to marketing theory by way of examining when and how surprise can be applied as a marketing tool. To reach this objective, the article conducted a thorough review of the existing literature on (1) the use of relationship-based marketing and emotion-based marketing and (2) the emotion of surprise. Moreover, the article conducted a review on empirical research on the emotion of surprise and its influence on marketing variables such as customer satisfaction and retention and trust. The main conclusions are that surprise can be an extremely efficient marketing tool, but that marketers need to be aware that some situations are more suited for using surprise than others.

Several aspects in relation to surprise remain, however, little explored, or even unexplored. For example, researchers could examine whether or not it is possible to determine what is a more profitable avenue for a company to pursue in the long run: to use surprise prior to a purchase (Box 5) so as to trigger more immediate purchases or to employ surprise after the purchase and during the consumption experience (Box 4) so that satisfactory rates of long-term sales are achieved due to high levels of customer satisfaction. Another research path would be to try to categorise customers into those who like to be surprised and those who do not (such customers could be called "surpriseaverse" consumers) and then to check for the potential moderating role of this variable on 
long-term customer satisfaction and loyalty. This path would need to include a scale development phase for the concept of surprise-aversion. A third research path is to examine more closely the process of schema-updated (e.g. what specific causal attributions and interpretations of the situation are at the origin of the updating) and, as a result, how best to communicate the surprising features so that such a process is avoided. Lastly, researchers might want to consider how the emotion of surprise is behind different marketing tools and phenomena. For example, it could be argued that the surprise mechanism is behind viral networks, which involves customers passing along a company's marketing message to their friends, family and colleagues, a process that resembles very much that of word-of-mouth marketing. Although originally designed to trigger purchase or increase customer satisfaction and loyalty, the long-term indirect effect of surprise strategies on a company's sales and its profitability should be investigated.

\section{References}

Aldred, J. (2000). "Word-of-mouse infects the Web", Internet World, May-June 2000, pp. $30-32$.

Anderson, R. E. (1973), "Consumer dissatisfaction: the effect of disconfirmed expectancy on perceived product performance", Journal of Marketing Research, Vol. 10, February, pp. 38-44.

Bainbridge, J. and Crutis, J. (1998), "On the ambient trail", Marketing, 11 September, pp. $35-39$. 
Barnes, J. G. (2001), Secrets of Customer Relationship Management: It's All About How You Make Them Feel, McGraw-Hill, London.

Bearden, W. O. and Teel, J. E., (1983), "Selected determinants of consumer satisfaction and complaints reports", Journal of Marketing Research, Vol. 20, No. 1, pp. 21-28.

Belch, G. E and Belch, M. A (1995), Introduction to Advertising and Promotion: An Integrated Marketing Communications Perspective, 3rd ed., Irwin, Homewood, Illinois.

Bell, C. R. and Zemke, R. E. (1987), "Service breakdown: the road to recovery", Management Review, October, pp. 32-35.

Best, R. J. (2004), Market-Based Management: Strategies for Growing Customer Value and Profitability, 3rd ed., Prentice Hall, Upper Saddle River, New Jersey.

Bolton, W. and Drew, J. H. (1991), "A multistage model of customers' assessment of service quality and value", Journal of Consumer Research, Vol. 17, No. 4, pp. 375384.

Boone, L. E. and Kurtz, D. L. (1999), Contemporary Marketing, The Dryden Press, London.

Borden, N. H. (1965), "The concept of the marketing mix", in Schwartz, G. (Ed.), Science in Marketing, John Wiley \& Sons, New York, pp. 386-397.

Boulaire, C. (2003), "Marketing relationnel: la carte d'anniversaire revisitée", Recherche et Applications en Marketing, Vol. 18, No. 1, pp. 43-63.

Brassington. F. and Pettitt, S. (2000), Principles of Marketing, 2nd ed., Financial Times / Prentice Hall: An imprint of Pearson Education, Harlow. 
Brodie, R. J., Coviello, N. E., Brookes, R. W. and Little, V. (1997), "Towards a paradigm shift in marketing? An examination of current marketing practices", Journal of Marketing Management, Vol. 13, No. 5, pp. 383-406.

Brookes, R. W., Brodie, R. J. and Lindgreen, A. (2000), "Contemporary marketing practice: understanding the trend towards the increased focus of financial accountability and value management", in Gummesson, E., Liljegren, G. and Feurst, O. (Eds.), Proceedings of the 8th International Colloquium in Relationship Marketing: Return on Relationships, 7-9 December, Stockholm University, Stockholm.

Brown, S. (2001), "Torment your customers (they'll love it)", Harvard Business Review, Vol. 79, No. 9, pp. 82-88.

Bruner, J. S. (1957), "On perceptual readiness", Psychological Review, Vol. 64, pp. 123152.

Buttle, F. A. (1997), "I heard it through the grapevine: issues in referral marketing", in Christopher, M. and Payne, A. (Eds.), Proceedings of the 5th International Colloquium in Relationship Marketing, Cranfield School of Management, Cranfield.

Charlesworth, W. R. (1969), "The role of surprise in cognitive development", in Elkind, D. and Flavel, J. H. (Eds.), Studies in Cognitive Development: Essays in Honor of Jean Piaget, Oxford University Press, Oxford, pp. 257-314.

Cigliano, J., Georgiadis, M., Pleasance, D. and Whalley, S. (2000), "The price of loyalty: do you know if your loyalty program is working?" The McKinsey Quarterly, No. 4, pp. 68-77. 
Cohen, J. B and Areni, C. S. (1991), "Affect and consumer behavior", in Robertson, T. S. and Kassrjian, H. H. (Eds.), Handbook of Consumer Theory and Research, Prentice Hall, Englewood Cliffs, New Jersey, pp. 188-240.

Colgate, M., Stewart, K. and Kinsella, R. (1996), "Customer defection: a study of the student market in Ireland", International Journal of Bank Marketing, Vol. 14, No. 3, pp. 23-29.

Coviello, N., Milley, R. and Marcolin, B. (2001), "Understanding IT-enabled interactivity in contemporary marketing," Journal of Interactive Marketing, Vol. 15, No. 4, pp. 1833.

Davis, S. and Meyer, C. (1998), Blur, Warner Books, New York.

Day, G. S. (2000), "Managing market relationships," Journal of the Academy of Marketing Science, Vol. 28, No. 1, pp. 24-30.

Derbaix, C. and Pham, M. T. (1989), "Pour un dévelopment des mesures de l'affectif en marketing", Recherches et Applications en Marketing, Vol. 4, No. 4, pp. 71-87.

Derbaix, C. and Pham, M. T. (1991), "Affective reactions to consumption situations: a pilot investigation", Journal of Economic Psychology, Vol. 12, No. 2, pp. 325-355.

Derbaix, C. and Vanhamme, J. (2003), Inducing Word-of-Mouth by Eliciting Surprise: A Pilot Investigation, unpublished manuscript, LABACC, Mons.

Desai, M. M. (1939), "Surprise: a historical and experimental study", British Journal of Psychology: Monographic Supplement, Vol. 22, 124 pages.

Dick, A. and Basu, K. (1994), "Customer loyalty: towards an integrated framework", Journal of the Academy of Marketing Science, Vol. 22, No. 2, pp. 99-113. 
Dowling, G. R. and Uncles, M. (1997), "Do customer loyalty schemes really work?" Sloan Management Review, Vol. 38, No. 4, pp. 71-82.

Doyle, P. (2000), Value-Based Marketing: Marketing Strategies for Corporate Growth and Shareholder Value, John Wiley \& Sons, Chichester.

Dwyer, F. R., Schurr, P. H. and Oh, S. (1987), "Developing buyer-seller relationships", Journal of Marketing, Vol. 51, No. 2, pp. 11-27.

Ekman, P. and Friesen, W. (1975), Unmasking the Face, Prentice-Hall, Englewood Cliffs, New Jersey.

Ekman, P. and Friesen, W. (1985), "Is the startle reaction an emotion?" Journal of Personality and Social Psychology, Vol. 49, No. 5, pp. 1416-1426.

Filser, M. (1996), "Vers une consommation plus affective?" Revue Française de Gestion, Vol. 110, pp. 90-99.

Fournier, S., Dobscha, S. and Mick, D. G. (1998), "Prevailing the premature death of relationship marketing", Harvard Business Review, Vol. 76, No. 1, pp. 42-51.

Gilbert, D. D. and Karabeyekian, V. (1995), "The frequent flyer mess: a comparison of programmes in the USA and Europe", Journal of Vacation Marketing, Vol. 1, No. 3, pp. 248-256.

Grönroos, C. (2000), Service Management and Marketing: A Customer Relationship Management Approach, 2nd ed., John Wiley \& Sons, Chichester.

Gummesson, E. (1999), Total Relationship Marketing: From the 4Ps - product, price, promotion, place - of traditional marketing management to the 30Rs - the thirty relationships - of the new marketing paradigm, Butterworth-Heinemann, Oxford. 
Heil, G., Parker, T. and Stephens, D. C. (1999), One Size Fits One: Building Relationships One Customer and One Employee at a Time, John Wiley \& Sons, New York.

Heilman, C. M., Nakamoto, K. and Rao, A. G. (2002), "Pleasant surprises: consumer response to unexpected in-store coupons", Journal of Marketing Research, Vol. 39, No. 2, pp. 242-252.

Heskett, J. L., Jones, T. O., Loveman, G. W., Sasser, W. E. Jr. and Schlesinger, L. A. (1994), "Putting the service profit-chain to work", Harvard Business Review, Vol. 72, No. 2, pp. 164-174.

Higgins, E. T. (1996), "Knowledge activation: accessibility, applicability, and salience", in Higgins, E. T. and Kruglanski, A. W. (Eds.), Social Psychology: Handbook of basic principles, Guilford, New York.

Hovland, C. L., Harvey, O. J. and Sherif, M. (1957), "Assimilation and contrast effects in reactions to communication and attitude change", Journal of Abnormal and Social Psychology, Vol. 55, July, pp. 244-252.

Hunt, S. D. (2000), A General Theory of Competition, Sage Publications, Thousand Oaks, California.

Izard, C. E. (1977), Human Emotions, Plenum Press, New York.

Jackson, B. B. (1985), Winning and Keeping Industrial Customers, Lexington Books, Lexington, Massachusetts.

Johnson, M. D. (1998), Customer Orientation and Market Action, Prentice Hall, Upper Saddle River, New Jersey. 
Jones, T. O. and Sasser, W. E. (1995), "Why satisfied customers defect", Harvard Business Review, Vol. 73, No. 6, pp. 88-99.

Levitt, T. (1969), The Marketing Mode: Pathways to Corporate Growth, McGraw-Hill, New York.

Levitt, T. (1980), "Marketing success through differentiation - of anything", Harvard Business Review, Vol. 58, No. 1, pp. 83-91.

Levitt, P. (1981), "Marketing intangible products and product intangibles", Harvard Business Review, Vol. 59, No. 3, pp. 94-102.

Lindgreen, A., Davis, R., Brodie, R. J. and Buchanan-Oliver, M. (2000), "Pluralism in contemporary marketing practice", The International Journal of Bank Marketing, Vol. 18, No. 6, pp. 294-308.

Lindgreen, A. and Pels, J. (2002), "Buyer-seller exchange situations: four empirical cases", Journal of Relationship Marketing, Vol. 1, No. 3/4, pp. 60-93.

Lovelock, C. (1994), Product Plus: How Product + Service = Competitive Advantage, McGraw-Hill, New York.

Lovelock, C. (1995), "Competing on service: technology and teamwork in supplementary services", Planning Review, July-August, pp. 32-39.

Mano, H. and Oliver, R. L. (1993), "Assessing the dimensionality and structure of the consumption experience: evaluation, feeling, and satisfaction", Journal of Consumer Research, Vol. 20, pp. 451-466.

Meyer, W.-U., Niepel, M., Rudolph, U. and Schützwöhl, A. (1994), "Überraschung und Attribution", in Försterling, F. and Stiensmeier-Pelster, J. (Eds.), Attributionstheorie, Hofgrefe, Göttingen, pp. 136-147. 
Mittal, B. and Lassar, W. M. (1998), "Why do customers switch? The dynamics of satisfaction versus loyalty", Journal of Services Marketing, Vol. 12, No. 3., pp. 177194.

Mitchell, A. (1995), "Preaching the loyalty message", Marketing Week, 1 December, pp. 26-27.

Morgan, R. M. and Hunt, S. D. (1994), "The commitment-trust theory of relationship marketing", Journal of Marketing, Vol. 58, No. 3, pp. 20-38

Niepel, M., Rudolph, U. and Schützwöhl, A. (1994), "Temporal characteristics of the surprise reaction induced by schema discrepant visual and auditory events", Cognition and Emotion, Vol. 8, pp. 433-452.

Oliver, R. L. (1997), Satisfaction: A Behavioral Perspective on the Consumer, McGrawHill, Singapore.

Oliver, R. L., Rust, R. T. and Varki, S. (1997), "Customer delight: foundations, findings, and managerial insight", Journal of Retailing, Vol. 73, No. 3, pp. 311-336.

Oliver, R. L. and Westbrook, R. A. (1993), "Profiles of consumer emotions and satisfaction in ownership and usage", Journal of Consumer Satisfaction/Dissatisfaction, and Complaining Behavior, Vol. 6, pp. 12-27.

O'Malley, L. (1998), "Can loyalty schemes really build loyalty?" Marketing Intelligence and Planning, Vol. 16, No. 1, pp. 47-55.

Palmer, A. (1998), Principles of Services Marketing, 2nd ed., McGraw-Hill, London.

Peck, H., Payne, A., Christopher, M. and Clark, M. (1999), Relationship Marketing: Strategy and Implementation, Butterworth-Heinemann, Oxford. 
Pine, B. J. and Gilmore, J. H. (1999), The Experience Economy, Harvard Business School Press, Boston, Massachusetts.

Plutchik, R. (1980), Emotion: A Psychoevolutionary Synthesis, Harper \& Row, New York.

Reichheld, F. F. (1996), The Loyalty Effect: The Hidden Force Behind Growth, Profits, and Lasting Value, Harvard Business School Press, Boston, Massachusetts.

Reisenzein, R., Meyer, W-U. and Schützwohl, A. (1996), "Reactions to surprising events: a paradigm for emotion research", in Frijda, N. H. (Ed.), Proceedings of the 9th Conference of the International Society for Research on Emotions, ISRE, Toronto, pp. 292-296.

Robinette, S., Brand, C. and Lenz, V. (2001), Emotion Marketing: The Hallmark Way of Winning Customers for Life, McGraw-Hill, New York.

Rumelhart, D. E. (1984), "Schemata and the cognitive system", in Wyer, R. S and Srull, T. K. (Eds.), Handbook of Social Cognition, Vol. 1, Lawrence Erlbaum Associates, Hillsdale, New Jersey, pp. 161-188.

Rust, R. T. and Oliver, R. L. (2000), "Should we delight the customer? Journal of The Academy of Marketing Science, Vol. 28, No. 1, pp. 86-94.

Rust, R. T., Zahorik, A. and Keiningham, T. L. (1996), Service Marketing, HarperCollins, New York.

Rust, R. T., Zeithaml, V. A. and Lemon, K. N. (2000), Driving Customer Equity: How Customer Lifetime Value Is Reshaping Corporate Strategy, The Free Press, New York. 
Scherer, K. R. (1984), "On the nature and function of emotion: a component process approach", in Scherer, K. R. and Ekman, P. (Eds.), Approaches to Emotion, Lawrance Erlbaum Associates Inc, Hillsdale, New Jersey, pp. 293-318

Schmitt, B. H. (1999), Experiential Marketing: How to Get Customers to Sense, Feel, Think, Act, and Relate to Your Company and Brands, The Free Press, New York.

Schneider, B. and Bowen, D. E., (1999), "Understanding customer delight and outrage", Sloan Management Review, Fall, pp. 35-45.

Schützwohl, A. (1998), "Surprise and schema strength", Journal of Experimental Psychology, Learning, Memory and Cognition, Vol. 24, No. 5, pp. 1182-1199.

Sheth, A. and Randall, G. (2001), The Grocers: The rise and rise of the supermarket chains, 2nd ed., Kogan Page, London.

Sheth, J. N. and Sisodia, R. S. (1999), "Revisiting marketing's lawlike generalisations", Journal of Academy of Marketing Science, Vol. 27, No. 1, pp. 71-87.

Stevens, M. (1992), "Integrated marketing", D\&B Reports, September-October, 50-51.

Storbacka, K., Strandvik, T. and Grönroos, C. (1994), "Managing customer relations for profit: the dynamics of relationship quality", International Journal of Service Industry Management, Vol. 5, No. 5, pp. 21-38.

Strauss, B. and Neuhaus, P. (1997), "The qualitative model satisfaction", International Journal of Service Industry Management, Vol. 8, No. 3, pp. 236-249.

Tomkins, S. S. (1980), "Affect as amplification: some modifications in theory", in Plutchik, P. and Kellerman, H. (Eds.), Emotion: Theory, Research and Experience: Theories of Emotion, Vol. 1, Academy Press, New-York, pp. 141-164. 
Vanhamme, J. (1999), "La surprise et son influence sur la satisfaction des consommateurs", Actes du 15e Congrès de l'Association Française du Marketing, Vol. 15, No. 2, pp. 809-839.

Vanhamme, J. (2000), "The link between surprise and satisfaction: an exploratory research on how best to measure surprise", Journal of Marketing Management, Vol. 16, No. 6, pp. 565-582.

Vanhamme, J. (2001), "L'influence de la surprise sur la satisfaction des consommateurs: étude exploratoire par journal de bord", Recherche et Applications en Marketing, Vol. 16, No. 2, pp. 1-32.

Vanhamme, J. (2002), La surprise et son influence sur la satisfaction des consommateurs: le cas de l'expérience de consommation/achat, PUL, Louvain-laNeuve.

Vanhamme, J. and Lindgreen, A. (2001a), "Gotcha: findings from an exploratory investigation on the dangers of using deceptive practices in the mail order business", Psychology \& Marketing, Vol. 18, No. 7, pp. 785-810.

Vanhamme, J. and Lindgreen, A. (2001b), "Surprise as a marketing tool?" in Chetty, E. and Collins, B. (Eds.), Bridging Marketing Theory and Practice: Proceedings of the Australia and New Zealand Marketing Academy Conference 2001, 3-5 December, Massey University, Auckland.

Vanhamme, J., Lindgreen, A. and Brodie, R. J. (1999), "Taking relationship marketing for a joyride: the emotion of surprise as a competitive marketing tool", in Cadeaux, J. and Uncles, M. (eds.), Marketing in the Third Millennium: Proceedings of the Annual 
Conference of the Australia and New Zealand Marketing Academy, 29 November - 1

December, University of New South Wales, Sydney.

Vanhamme, J., Lindgreen, A. and Brodie, R. J. (2000), "Passion or rationalism: emotional determinants versus rational determinants of customer delight in service processes", in Wierenga, B., Smidts, A. and Antonides, G. (Eds.), Marketing in the New Millennium: Proceedings of the Annual Conference of the European Marketing Academy, 23-26 May, Erasmus University Rotterdam, Rotterdam.

Vanhamme, J. and Snelders, D. (2001), "The role of surprise in satisfaction judgements"? Journal of Consumer Satisfaction, Dissatisfaction and Complaining Behavior, Vol. 14, pp. 27-45.

Webster, F. E (2000), "Understanding the relationships among brands, customers and resellers," Journal of the Academy of Marketing Science, Vol. 28, No. 1, pp. 17-23.

Westbrook, R. A. (1987), "Product/consumption-based affective responses and postpurchase process", Journal of Marketing Research, Vol. 24, pp. 258-270.

Westbrook, R. A. and Oliver, R. L. (1991), "The dimensionality of consumption emotion patterns and consumer satisfaction", Journal of Consumer Research, Vol. 18, No. 1, pp. 84-91.

Wyer, R. S. and Srull, T. K. (1989), Memory and Social Cognition in its Social Context, Erlbaum, Hillsdale, New Jersey.

Yu, Y.-T. and Dean, A. (2001), "The contribution of emotional satisfaction to consumer loyalty", International Journal of Service Industry Management, Vol. 12, No. 3, pp. 234-250. 


\section{Autobiographical Notes}

Dr. Adam Lindgreen holds a PhD in Marketing from Cranfield University (England). He works with the Eindhoven University of Technology (the Netherlands).

Dr. Joëlle Vanhamme holds a PhD in Marketing from the Catholic University of Louvain

(Belgium). She previously worked as a consultant in Belgium and Germany, but now works with the Erasmus University Rotterdam (the Netherlands). 


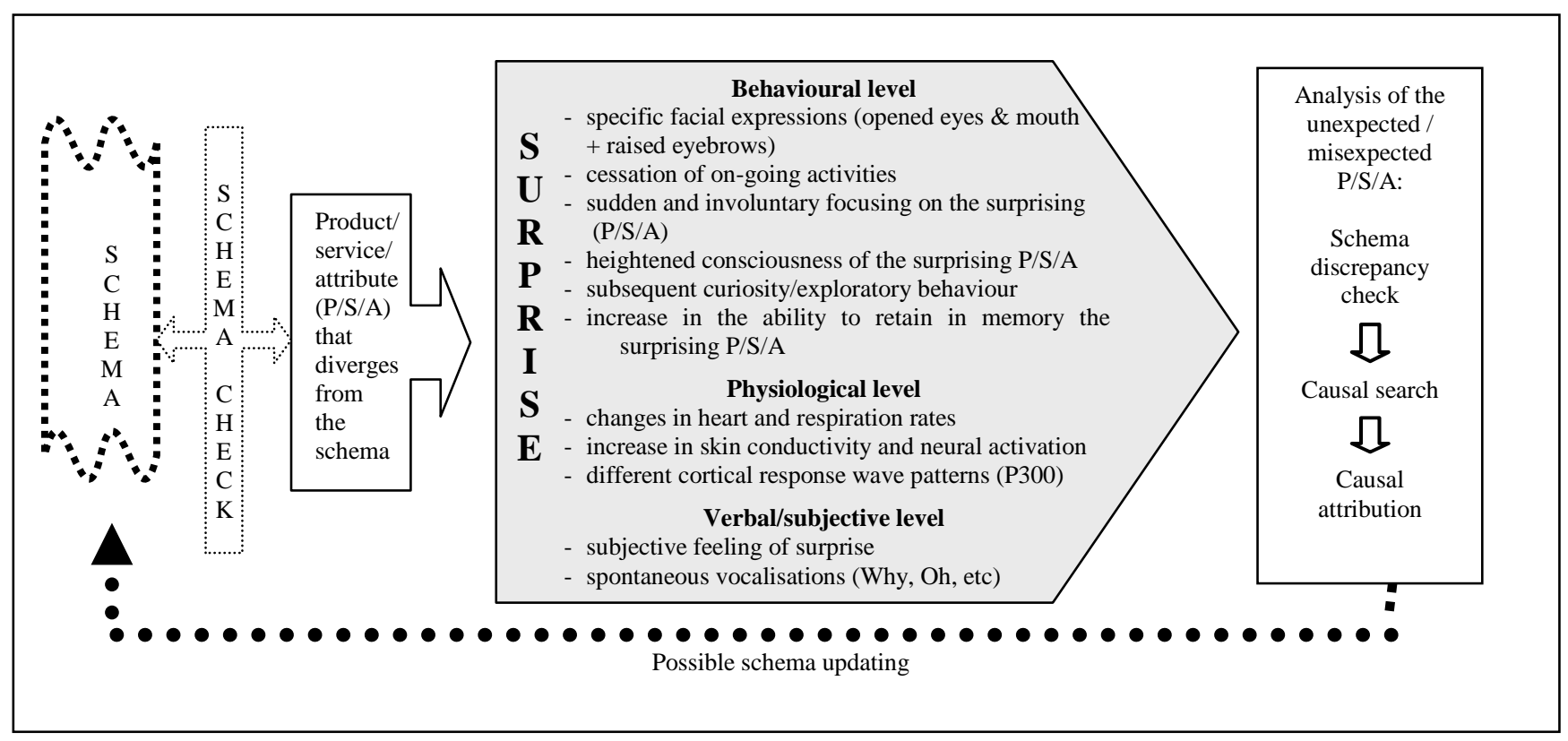

\section{Figure 1. The emotion of surprise}

Note: Reprinted with permission from Vanhamme, J. (2000), "The link between surprise and satisfaction: an exploratory research on how best to measure surprise," Journal of Marketing Management, Vol. 16, No. 6, p. 567. Copyright 2000 Westburn Publishers www.westburn.co.uk. 


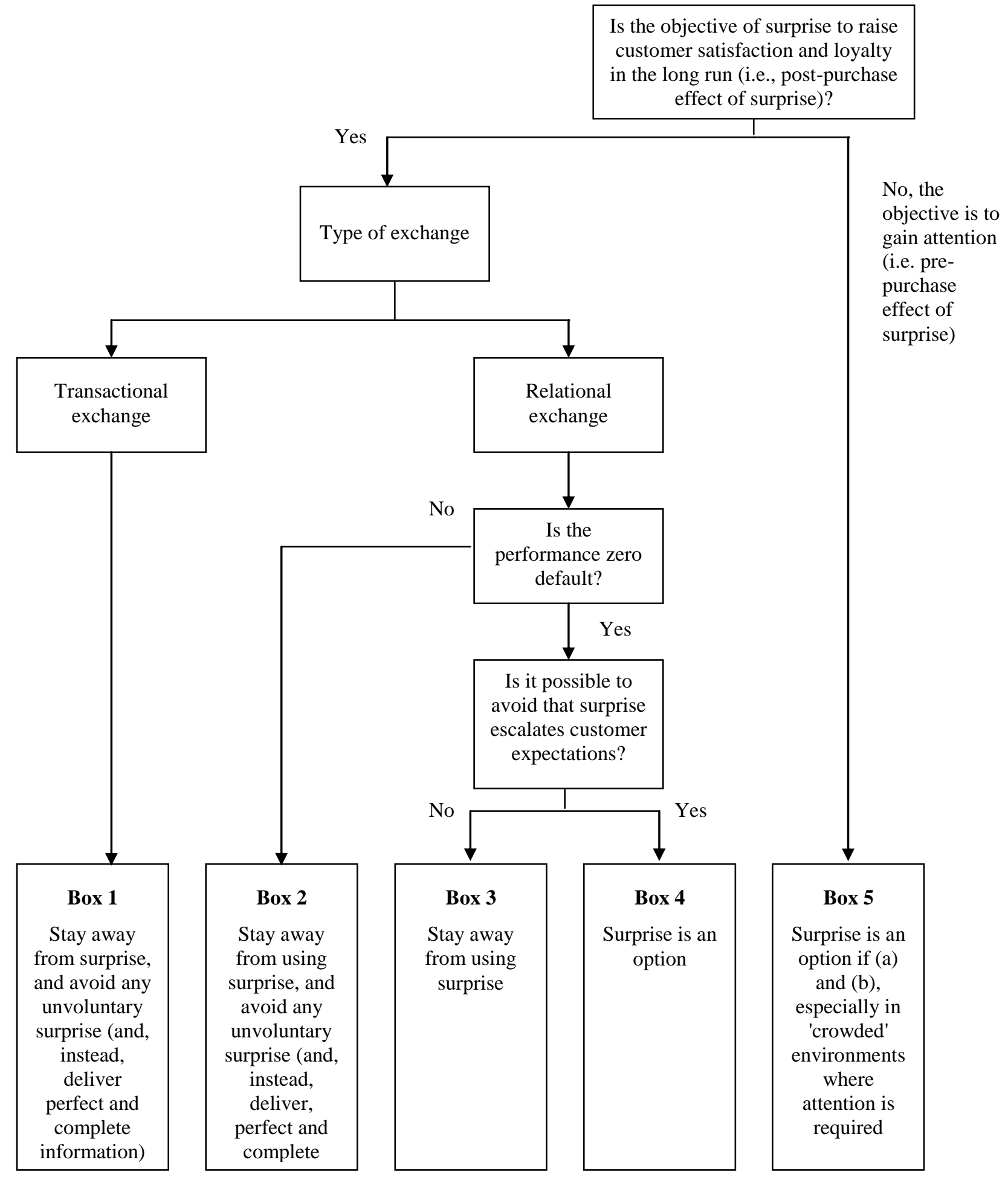

\section{Figure 2. When to use positive surprise, and when not to use it}

Note: (a) Other marketing tools have been implemented in order to achieve the goals of satisfaction and loyalty. (b) Surprise does not jeopardise future profits for the company. 
Table I. Rules for loyalty schemes

\begin{tabular}{ll}
\hline Pricing & Be customer specific - reward the best \\
Purchases & Make product-specific offers \\
Point flexibility & Occasionally offer double points, for example \\
Partners & Develop alliances with other retailers \\
Prizes & Weekly prize draw for cardholders, for example \\
Pro-bono & Allow customers to convert points into charity donations \\
Personalization & Direct mail, specifically targeted at customer \\
Privileges & Invite cardholders to special events, for example \\
Participation & Invite best customers to take part in new variations of scheme \\
Pronto & Generate offers at the point of sale \\
Proactive & Use information to predict/pre-empt customer behaviour \\
\hline
\end{tabular}

Source: Adapted from Mitchell, A. (1995), "Preaching the loyalty message", Marketing Week, 1 December, pp. 26-27. 


\section{Table II. Mixtures of primary emotions including}

- $\quad$ Surprise + fear $=$ alarm, awe

- $\quad$ Surprise + sadness $=$ disappointment, embarrassment

- $\quad$ Surprise + anger $=$ outrage

- Surprise + acceptance $=$ curiosity

- $\quad$ Surprise + joy $=$ delight

Source: This table is based upon a larger table from Plutchik, R. (1980), Emotion: A Psychoevolutionary Synthesis, Harper \& Row, New York. 